\title{
Climate change in context: putting people first in the Arctic
}

\author{
Henry P. Huntington ${ }^{1}$ (1) $\cdot$ Mark Carey $^{2} \cdot$ Charlene Apok $^{3} \cdot$ Bruce C. Forbes $^{4} \cdot$ Shari Fox ${ }^{5} \cdot$ Lene K. Holm $^{6}$. \\ Aitalina Ivanova ${ }^{7,8} \cdot$ Jacob Jaypoody $^{9} \cdot$ George Noongwook $^{10} \cdot$ Florian Stammler $^{4}$
}

Received: 2 November 2018 / Accepted: 14 February 2019 /Published online: 6 March 2019

(C) The Author(s) 2019

\begin{abstract}
Climate change is a major challenge to Arctic and other Indigenous peoples, but not the only and often not the most pressing one. We propose re-framing the treatment of climate change in policy and research, to make sure health, poverty, education, cultural vitality, equity, justice, and other topics highlighted by the people themselves and not just climate science also get the attention they deserve in research on global and regional environmental change. Climate change can often exacerbate other problems, but a singular focus on climate change - as is often the case in much existing environmental literature on the Arctic and elsewherecan distract from actions that can be taken now to improve the lives of Arctic peoples. The same logic also applies elsewhere in the world, where diverse residents face a host of challenges, opportunities, and obstacles, with climate change but one among many issues. Our proposed approach to regional and global environmental change research draws on the ideas of decolonization, emphasizing collaborative approaches and Indigenous voices in research and policy instead of top-down measures designed outside the affected communities. Only in this way of contextualizing human-environmental experiences can the full effects of climate change be understood - and appropriate responses developed and carried out to adapt to global change.
\end{abstract}

Keywords Indigenous peoples $\cdot$ Climate change $\cdot$ Decolonization $\cdot$ Arctic $\cdot$ Andes

For Indigenous communities in the Arctic and elsewhere, climate change poses a major challenge now and in the decades to come (AMAP 2017; Rosen 2017; Watt-Cloutier 2015), deserving the considerable scientific and media attention it attracts. And yet, it is but one among many major challenges,

Editor: James D. Ford

\section{Highlights}

- Arctic and other Indigenous peoples face many challenges, not just climate change

- It is essential to understand community contexts in which change occurs

- Decolonizing methodologies can help put community concerns first

- Putting community concerns first will help lead to more effective actions

Henry P. Huntington

henryphuntington@gmail.com

Mark Carey

carey@uoregon.edu

Charlene Apok

capok@southcentralfoundation.com

Bruce C. Forbes

bruce.forbes@ulapland.fi

Shari Fox

shari.fox@nsidc.org and often far from the most immediate concern, for many Arctic peoples as for others around the world (Forbes and Stammler 2009, Cameron 2012, 2017; Ford et al. 2015; Huntington and Eerkes-Medrano 2017). This point is noted in the foundational literature on natural hazards (e.g., Blaikie

\author{
Lene K. Holm \\ leho@natur.gl \\ Aitalina Ivanova \\ ivanovaaytalina@mail.ru \\ George Noongwook \\ gnunguk@hotmail.com \\ Florian Stammler \\ florian.stammler@ulapland.fi
}

Extended author information available on the last page of the article 
et al. 1994, Cutter 2006), food security (e.g., Bohle et al. 1994), and vulnerability and adaptation (e.g., Smit and Wandel 2006), and put into practice in some studies to date (e.g., McCubbin et al. 2017, Prno et al. 2011, Tyler et al. 2007), such as those examining multiple stressors to climate change (e.g., Bunce et al. 2010, McDowell and Hess 2012, Reid and Vogel 2006). Yet many studies still retain a central focus on climate even as they consider multiple factors that affect people; they can thus overlook or minimize the principal concerns, knowledge, politics, livelihoods, experiences, and priorities of people themselves as research agendas driven by outsiders' focus on climate change rather than the people themselves. By contrast, the lived experiences of health and health care, economic viability, sustaining culture and language, food security, effects from extractive industries, even dealing with the day-to-day demands of existence in remote areas and under extreme climates tend to dominate discussions among and led by Arctic residents themselves (Gearheard et al. 2013; Stuhl 2016).

Although researchers recognize that climate change can exacerbate all of these in its relentless march to replace what is known with the unfamiliar (e.g., Hovelsrud and Smit 2010), focusing on climate change as the only or the primary threat misses much that is more pressing and worrisome. The amount of attention given singularly to climate change in and of itself, as opposed to climate in the context of numerous other risks, can even distract from what matters to Arctic communities, such as high rates of poverty, suicide, substance abuse, limited access to health care, inadequate housing, unsafe drinking water, low educational attainment, food insecurity, and a host of other difficulties (CCA 2014; Forbes and Stammler 2009; Inuit Circumpolar Council-Alaska 2015). What is more, the singular climate focus that comes in highprofile reports from the IPCC, global conventions such as the Paris Agreement, and international conferences such as the annual COP meetings can produce policies or adaptation agendas that primarily address climate change but may not respond to these other, more pressing needs and wishes of Arctic peoples.

We propose an alternative. We want to de-center climate as the dominant issue in the Arctic, to go beyond atmospheric changes and sea ice extent to focus additionally on societal conditions, contexts, and risks, of which climate change is but one part at the local and regional level (e.g., Hovelsrud and Smit 2010; Rasmussen et al. 2015). This approach should yield policies more directly relevant for the needs and interests of local residents and communities. An outsized focus on climate alone generates certain types of mitigation agendas, namely reducing greenhouse gasses by nations and corporations in the Global North, rather than addressing multiple and intersecting issues related to health, poverty, education, economic viability, cultural vitality, and justice. This emissionsoriented approach exemplified in the Paris Agreement and other COP decisions, for example, also privileges particular actors to "solve" climate change - usually the national and international policymakers representing those countries and entities most responsible for emitting greenhouse gasses in the first place, rather than seeking ideas and actions from those who live in the Arctic and depend upon its resources for their livelihoods.

Climate change in context emphasizes people in relationship to the environment, not just the air and the ice in the focus on degrees $\mathrm{C}$ and shrinking glaciers and sea ice. Arctic residents have long lived amid ongoing environmental change, to which they have responded over time (Piper 2012, Hastrup 2018). (Here, we use responses and adaptations to refer to local and regional measures taken in response to change, in contrast to mitigation efforts taken globally to reduce the causes of climate change.) Arctic residents continue to demonstrate remarkable innovation, resilience, flexibility, humor, and perseverance in the face of changes that have swept through the entire region in recent decades (e.g., Fawcett et al. 2018, Kirmayer et al. 2009, Pearce et al. 2015). Predictions of gloom and doom from a changing climate ignore these capabilities and histories. Framings of climate apocalypse - the lonely polar bear drifting on a vanishing piece of ice, for instance-ignore history and deny the place of people in their past, present, and future (Cameron 2012; Liverman 2009; Stuhl 2016; Swyngedouw 2010).

Moreover, this privileging of emissions-oriented decisions made in Bonn and Paris and Washington-while simultaneously relegating Indigenous knowledge solely to the Arctic and other localized regions - can serve to bound Indigenous peoples within local landscapes and local politics, denying them a global voice in processes profoundly affecting their communities (Cameron 2017). Worse, the apocalyptic projections can even become their own fulfillment, if Arctic residents come to believe that their ways of life are done for. This becomes particularly dangerous through the multipliers of the mass media, especially when the effects of change on Indigenous livelihoods turn into simplistic messages such as "Vanishing Arctic Culture" (a cover headline on the October 2017 issue of National Geographic) or "Alaska's Vanishing Ice Threatens to Destroy Cultures" (a Guardian headline on 14 December 2018). Instead, while climate change is undoubtedly transforming the Arctic, people continually observe and think about the ways they can take care of one another as they have always done, through larger changes than those of recent climatic origin (Harcharek and Rexford 2015).

Current climatic and global environmental changes may be proceeding at profound and perhaps unprecedented rates (Serreze 2018), but such changes do not remove histories of adaptability and resilience in the past and present (Adamson et al. 2018; Cameron 2012; Ford et al. 2015; Hovelsrud and Smit 2010; Stuhl 2016, Hastrup 2018). More research is needed on all that Arctic peoples have done, continue to do, and are 
likely to do in the future. This research can-and must-tell more than the story of how old ways no longer work. Stories in this realm are important but incomplete.

To counter the all-too-common impressions of vanishing cultures, a greater focus is needed on adaptability and innovativeness (Stammler 2013). Innovation by definition is something new, so specific innovations cannot be predicted, but we can certainly expect innovations to occur. The Yupik on St. Lawrence Island, Alaska, have created a winter whaling season (Noongwook et al. 2007). Evenki, Sakha, Yamal-Nenets, Khanty, and other reindeer herders in Siberia have added ethno-tourism, traditional arts and crafts production for sale, and other activities to their livelihoods (Novikova \& Karpov 2017). The Inughuit of northern Greenland have started a commercial halibut fishery (Berthelsen 2014), and residents in Clyde River, Nunavut, have established a research center that runs Inuit-led research projects (Ittaq 2019). Understanding and creating the conditions that foster innovation is a more useful contribution to the well-being of Arctic communities than speculating about what climate-related disaster will next befall them.

This leads to our main point: that research and policies that aim to serve the needs of Indigenous communities must consider climate change - and related adaptation measures and policies - in deeper historical and present-day contexts in which the many forces and issues affecting people are recognized and accounted for. This re-framing of Arctic research around deeper socio-ecological contexts and community needs, and towards a collaborative approach, goes beyond ever-increasing calls for more integration of the humanities and social sciences into global environmental change research (Castree 2016; Castree et al. 2014; Hulme 2017), the demands for more recognition of Indigenous knowledge alongside the natural sciences (Arctic Council Indigenous Peoples Secretariat n.d.), and the requests for greater analysis of nonclimatic factors that influence the viability of climate change adaptation agendas (e.g., Ford et al. 2015). Our approach strives to redirect and connect the social, natural, and life sciences integral to global environmental change research to help understand - and ultimately resolve - broader societal and environmental issues, with climate as one among many issues in the Arctic. Climate change is generating major impacts on Arctic societies and is thus rightly the target of advocacy by Arctic Indigenous organizations (e.g., Sakakibara 2009) but should not obscure the range of other factors affecting people's lives, potentially exacerbated by climate change, and the urgency of those concerns (e.g., Inuit Circumpolar Council-Alaska 2015).

To move in that direction, we should start with communities, trying to see the world the way they see it rather than according to a particular disciplinary or institutional or policy lens. Such an approach - we argue - also redirects the orientation of research. Namely from science for its own sake towards science on agendas by and under the direction of Arctic residents themselves. In some cases, the roles are even turned upside down, where scientists take on the role of assistants that is usually reserved for local people in conventional science. Among other things, the local perspective is likely to emphasize relationships among the inhabitants of an ecosystem, human and otherwise, animate and inanimate (Gearheard et al. 2013; Hastrup 2013; Kawagley 2006; Krupnik et al. 2010). In this framing, for example, sea ice is not just an emblematic icon of global temperature change threatening homogenous, faceless populations, as media often portray Arctic ice. Rather, sea ice studies should also focus on cultural values and transportation, subsistence hunting and language vitality, health and security, knowledge and politics, community interactions, and intergenerational sharing. This is the direction that research on ice has taken worldwide, because glaciers, icebergs, and sea ice are more than just water receptacles. Ice must also be understood as cultural beacons, sentient willful beings, sites of spiritual pilgrimages, landscapes of identity, economic resources, politicized entities, deadly sources of outburst floods and avalanches, and recreational terrain (e.g. Bravo and Rees 2006, Carey 2007, Huggel et al. 2015; Cruikshank 2012, Hastrup 2018, Orlove et al. 2008, Radin and Kowal 2017, Ruiz 2015).

After this start, community members can engage with researchers as a means of contributing local ways of knowing to more general debates. People everywhere must rank a series of risks and challenges in their lives; they must grapple with multiple and often compounding stressors. Climate change impacts may not always be the most pressing issue they face. Or climate change may exacerbate other problems - such as social inequality, poverty, dwindling access to natural resources, inadequate health care (Cameron 2012; Huntington and Eerkes-Medrano 2017; Stuhl 2016) —so that focusing solely on climate problems and solutions targets only the tip of the iceberg, a superficial approach that leaves the deeper risks to individuals or communities unresolved.

The local perspective is also likely to see connections between topics that might seem separate from the outside (Cameron 2012; Flynn et al. 2018). The idea that traditional hunting and fishing contribute to health and well-being is by now better understood, through pride and competence and identity as well as a healthy diet (Bersamin et al. 2007; CCA 2014; Cunsolo Willox et al. 2012). Less often, however, do academic studies or government policies act on, say, the role of transportation difficulties on health and health care, or the social effects of inadequate infrastructure (Hansen et al. 2016). Among other ways to improve this myopia, the growing presence and voice of Elders and Indigenous scholars can help point research in directions that matter to, and make sense to, Arctic communities (Hiratsuka et al. 2017).

As one example, a focus on relationships and community needs illustrates that sea ice is not just an obstacle to shipping, as World Meteorological Organization terminology implies (Gearheard et al. 2013; Hastrup 2013; Krupnik et al. 2010), 
nor simply a mirror whose loss creates a positive feedback for warming (Euskirchen et al. 2013). Sea ice is also home, a source of a sense of freedom and belonging, a "beautiful garden," in the words of Wesley Aiken, an Iñupiaq Elder from Alaska (Gearheard et al. 2013:xii). An icebreaker that cuts a path for a cargo ship may also be severing local travel routes, disrupting marine mammals with noise, and demolishing seal dens (Wilson et al. 2017). None of these views captures the whole story, and it is hard to make ethical choices on the basis of a single perspective. Similarly, pipelines, roads, and powerlines through the lands of Siberian forest and tundra dwellers provide energy and economic growth and make it easier for people to connect with one another. At the same time, they also separate people from the land, interrupt migration patterns, and undermine environmental stability and income (Sidortsov et al. 2016).

As global environmental change research projects take a more community-centered approach (Johnson et al. 2016; Klenk and Meehan 2015), it is worth thinking more about how the research process and products can benefit communities. Conference presentations and peer-reviewed papers are all well and good, helping among other things to build a coherent body of work so that tested ideas can be recognized and new ideas explored. For an Indigenous community, however, it is less likely that a visiting researcher can interpret results in a full local context. This is not to say that academics have no role, simply that the old hierarchy separating those who do the studying from those who are studied is too often a hindrance both to research and community benefits from that research. Instead, it is more useful to include local resident experts as fellow researchers and collaborators, and to consult with and involve local leaders and community members from the outset to ensure that research ultimately yields information that local people can interpret, utilize, and apply themselves (e.g., Berkes and Jolly 2001; Flynn et al. 2018; Gearheard and Shirley 2007). This approach engages local experts as intellectual partners rather than as sources of information that will be analyzed by someone else, somewhere else.

Our call here in Climate Change in Context strives to focus first on people and communities, with climate as but one issue facing them - and our call thus contributes to ongoing efforts to decolonize and establish self-determination in education, science, and research (e.g., Cunsolo and Hudson 2018; ITK 2018; Pfeifer 2018). This involves a shift in roles and approach: communities are no longer "the studied," nor even just "local experts." Scientists acknowledging from their intellectually high position that local knowledge "is also worth considering," and therefore "allowing people to become participants" does not yet change the nature of the collaboration from a patron-client relationship to one of equal participation. The decolonizing framework demands a deep contextualization of research within historical and ongoing forces affecting Indigenous and other marginalized peoples (Lightfoot 2016; Smith 2012). Decolonizing methodologies can also help shift climate change from the key issue to, instead, just one recent manifestation of a long history of external forces affecting Indigenous communities (Cameron 2012; Stuhl 2016). The Inuit Circumpolar Council-Alaska (2015) focus on food security and food sovereignty is one example of an Indigenous organization determining for itself the scope of its research rather than responding to academic trends or political expedience.

Researchers can also consider the ways that government, laws, policymaking practices, and other institutional and bureaucratic structures shape the ability of Indigenous communities to attain the futures they would like to see (Stammler and Ivanova 2016a), including their responses to climate change. Arctic peoples continue to adjust their own activities to take advantage of new opportunities or to reduce the effects of unfavorable conditions (Gadamus and Raymond-Yakoubian 2015). International, national, regional, and even local institutions all too often function as barriers to local responses and adaptations (Huntington et al. 2017). Documenting vulnerabilities and problems associated with climate change has some value, in drawing attention where it is needed, but more must be done - particularly by looking beyond climate change and instead seeing the Arctic (and other regions) as facing many obstacles and opportunities. Partnering with Indigenous communities can help turn information and knowledge into action. For example, knowledge about negative impacts of a pipeline has led Indigenous activists in Siberia (Yakutia) to push for legislation that requires assessment of industrial impacts on culture and Indigenous livelihoods (Stammler and Ivanova 2016b). Likewise, Nenets representatives in northeastern Europe have approached scientists to assist them in developing a monitoring program of the simultaneous use of the tundra by large-scale oil extraction and nomadic reindeer herding. The insights produced from such assessment were used by Indigenous activists in their negotiations with authorities and the industry about support for traditional livelihoods (Dallman et al. 2011).

Research does not exist on its own. Whether or not scientists deliberately choose to advocate for social and political change, the knowledge produced is nested within a social system that also includes policies, practices, and activism to call for needed change. Again drawing on the example of sea ice specifically and ice (glaciers, icebergs, etc.) more broadly, it seems that research framed primarily around ice and climate change can actually obscure these community impacts, responses, meanings, politics, and even hydrological processes. After all, ice is embedded with cultural values and understandings, political authority and power imbalances, economic priorities in icecovered regions, technologies, and water and land use practices for farming, drinking, transportation, and hydroelectricity generation (Hastrup 2018, Huggel et al. 2015, Orlove et al. 2008). Thus, just as researchers have concluded that climate change alone rarely drives human migration (Black et al. 2011, Hamilton et al. 2016), research shows that climatic variability and ice loss also interact with a host of social, cultural, 
economic, political, and technological forces to influence water security and community well-being (Bravo and Rees 2006, Carey et al. 2017, Hastrup 2013). Framing issues in the Arctic solely or even primarily as climate or ice problems can thus ignore the underlying issues playing out in local communities, as if sea ice and human-ice interactions more broadly were divorced entirely from their societal contexts.

Climate change cannot and should not be removed from the list of topics to study and resolve, but it must be placed into context and perspective, to make sure that research about and involving Arctic Indigenous communities, and communities worldwide, takes a more holistic approach (Barnes et al. 2013). Individual projects may focus on one or another of the many aspects of climate change that are so apparent all around the region. Collectively, however, the research community has a tremendous opportunity and an ethical responsibility (Holm et al. 2011) to look more carefully at the world from Indigenous perspectives, to consider how information is and can be used for the benefit of Arctic communities, and to align our efforts and policies accordingly. Climate Change in Context asks us to reframe climate change as one among many issues facing communities and societies because framing these issues solely as climate problems can actually distract and disorient research away from more pressing and profound underlying issues. Climate Change in Context insists that climate change can only be understood - and adaptation measures and policies can therefore only be designed effectively - if climate is put into deeper historical and present-day contexts in which the many forces and issues affecting people are recognized and accounted for.

Funding This essay arose from discussions during the project "RCN: Learning from Indigenous Community-Based Researchers Engaged in Science Around the Arctic," funded by the U.S. National Science Foundation (award no. 1503884). A portion of this work is also funded by the National Science Foundation under grant no. 1253779. A portion of this work is also funded by the RFBR project 18-59-11001.

Open Access This article is distributed under the terms of the Creative Commons Attribution 4.0 International License (http:// creativecommons.org/licenses/by/4.0/), which permits unrestricted use, distribution, and reproduction in any medium, provided you give appropriate credit to the original author(s) and the source, provide a link to the Creative Commons license, and indicate if changes were made.

Publisher's note Springer Nature remains neutral with regard to jurisdictional claims in published maps and institutional affiliations.

\section{References}

Adamson GCD, Hannaford MJ, Rohland EJ (2018) Re-thinking the present: the role of a historical focus in climate change adaptation research. Glob Environ Chang 48:195-205. https://doi.org/10.1016/j. gloenvcha.2017.12.003
AMAP (2017) Adaptation actions for a changing Arctic. Arctic Monitoring and Assessment Programme, Oslo

Arctic Council Indigenous Peoples Secretariat (n.d.) Ottawa Traditional Knowledge Principles. Arctic Council Indigenous Peoples Secretariat, Copenhagen

Barnes J, Dove M, Lahsen M, Mathews A, McElwee P, McIntosh R, Moore F, O’Reilly J, Orlove B, Puri R, Weiss H, Yager K (2013) Contribution of anthropology to the study of climate change. Nat Clim Chang 3:541-544. https://doi.org/10.1038/nclimate1775

Berkes F, Jolly D (2001) Adapting to climate change: social-ecological resilience in a Canadian western Arctic community. Conserv Ecol 5(2):18. http://www.consecol.org/vol5/iss2/art18/

Bersamin A, Zidenberg-Cherr S, Stern JS, Luick BR (2007) Nutrient intakes are associated with adherence to a traditional diet among Yupik Eskimos living in remote Alaska native communities: the CANHR study. Int J Circumpolar Health 66(1):62-70. https://doi. org/10.3402/ijch.v66i1.18228

Berthelsen T (2014) Coastal fisheries in Greenland. KNAPK, Nuuk

Black R, Adger NW, Arnell NW, Dercon S, Geddes A, Thomas D (2011) The effect of environmental change on human migration. Glob Environ Chang 21(Supplement 1):3-11. https://doi.org/10.1016/j. gloenvcha.2011.10.001

Blaikie PM, Cannon T, Davis I, Wisner B (1994) At risk: natural hazards, people's vulnerability, and disasters. Routledge, London

Bohle HG, Downing TE, Watts MJ (1994) Climate change and social vulnerability: toward a sociology and geography of food insecurity. Glob Environ Chang 4(1):37-48. https://doi.org/10.1016/09593780(94)90020-5

Bravo M, Rees G (2006) Cryo-politics: environmental security and the future of Arctic navigation. Brown J World Affairs 12:205-215. http://www.jstor.org/stable/24590654

Bunce M, Rosendo S, Brown K (2010) Perceptions of climate change, multiple stressors and livelihoods on marginal African coasts. Environ Dev Sustain 12:407-440. https://doi.org/10.1007/s10668009-9203-6

Cameron ES (2012) Securing indigenous politics: a critique of the vulnerability and adaptation approach to the human dimensions of climate change in the Canadian Arctic. Glob Environ Chang 22:103114. https://doi.org/10.1016/j.gloenvcha.2011.11.004

Cameron E (2017) Climate anti-politics: scale, locality, and arctic climate change. In: Bocking S, Martin B (eds) Ice blink: navigating northern environmental history. University of Calgary Press, Calgary, pp 465-495

Carey M (2007) The history of ice: how glaciers became an endangered species. Environ Hist 12:497-527. https://doi.org/10.1093/envhis/ 12.3.497

Carey M, Molden OC, Rasmussen MB, Jackson M, Nolin AW, Mark BG (2017) Impacts of glacier recession and declining meltwater on mountain societies. Ann Am Assoc Geogr 107:350-359. https:// doi.org/10.1080/24694452.2016.1243039

Castree N (2016) Broaden research on the human dimensions of climate change. Nat Clim Chang 6:731. http://ro.uow.edu.au/sspapers/2499

Castree N, Adams WM, Barry J, Brockington D, Büscher B, Corbera E, Demeritt D, Duffy R, Felt U, Neves K, Newell P, Pellizzoni L, Rigby K, Robbins P, Robin L, Rose DB, Ross A, Schlosberg D, Sörlin S, West P, Whitehead M, Wynne B (2014) Changing the intellectual climate. Nat Clim Chang 4:763-768. https://doi.org/10. 1038 /nclimate2339

CCA (2014) Aboriginal food security in northern Canada: an assessment of the state of knowledge. The Expert Panel on the State of Knowledge of Food Security in Northern Canada. Council of Canadian Academies, Ottawa

Cruikshank J (2012) Are glaciers 'good to think with'? Recognising Indigenous environmental knowledge. Anthropol Forum 22:239 250. https://doi.org/10.1080/00664677.2012.707972 
Cunsolo A, Hudson A (2018) Relationships, resistance \& resurgence in northern-led research. Northern Public Affairs 6(1):23-29

Cunsolo Willox A, Harper SL, Ford JD, Landman K, Houle K, Edge VL, the Rigolet Inuit Community Government (2012) "From this place and of this place:" climate change, sense of place, and health in Nunatsiavut, Canada. Soc Sci Med 75:538-547. https://doi.org/10. 1016/j.socscimed.2012.03.043

Cutter S (ed) (2006) Hazards, vulnerability and environmental justice. Earthscan, Abingdon

Dallman WK, Peskov V, Murashko OA, Khmeleva E (2011) Reindeer herders in the Timan-Pechora oil province of Northwest Russia: an assessment of interacting environmental, social, and legal challenges. Polar Geogr 34:229-247. https://doi.org/10.1080/ 1088937X.2011.632826

Euskirchen ES, Goodstein ES, Huntington HP (2013) An estimated cost of lost climate regulation services caused by thawing of the Arctic cryosphere. Ecol Appl 23:1869-1880. https://doi.org/10.1002/eap. 2013.23.8.i

Fawcett D, Pearce T, Notaina R, Ford JD, Collings P (2018) Inuit adaptability to changing environmental conditions over an 11-year period in Ulukhaktok, Northwest Territories. Polar Record 54(2):119-132. https://doi.org/10.1017/S003224741800027X

Flynn M, Ford JD, Pearce T, Harper SL (2018) Participatory scenario planning and climate change impacts, adaptation and vulnerability research in the Arctic. Environ Sci Pol 79:45-53. https://doi.org/10. 1016/j.envsci.2017.10.012

Forbes BC, Stammler F (2009) Arctic climate change discourse: the contrasting politics of research agendas in the West and Russia. Polar Res 28:28-42. https://doi.org/10.1111/j.1751-8369.2009.00100.x

Ford JD, McDowell G, Pearce T (2015) The adaptation challenge in the Arctic. Nat Clim Chang 5:1046-1053. https://doi.org/10.1038/ nclimate2723

Gadamus L, Raymond-Yakoubian J (2015) A Bering Strait Indigenous framework for resource management: respectful seal and walrus hunting. Arct Anthropol 52:87-101. https://doi.org/10.3368/aa.52. 2.87

Gearheard S, Shirley J (2007) Challenges in community-research relationships: learning from natural science in Nunavut. Arctic 60(1): 62-74. https://doi.org/10.14430/arctic266

Gearheard SF, Holm LK, Huntington HP, Leavitt JM, Mahoney AR, Opie M, Oshima T, Sanguya J (2013) The meaning of ice: people and sea ice in three Arctic communities. IPI Press, Hanover

Hamilton LC, Saito K, Loring PA, Lammers RB, Huntington HP (2016) Climigration? Population and climate change in Arctic Alaska. Popul Environ 38:115-133. https://doi.org/10.1007/s11111-016$0259-6$

Hansen AM, Tepecik Dis A, Chatwood S, Holdmann G, Lantz T, Chamberlain L, Virginia R (2016) Community wellbeing and infrastructure in the Arctic. Danish Centre for Environmental Assessment. Aalborg, Department of Planning and Development, Aalborg University

Harcharek PJ, Rexford CT (2015) Remembering their words, evoking Kinuniivut: the development of the Iñupiaq learning framework. J Am Indian Educ 54(2):9-28. http://www.jstor.org/stable/10.5749/ jamerindieduc.54.2.0009

Hastrup K (2013) The ice as argument: topographical mementos in the high Arctic. Camb Anthropol 31:51-67. https://doi.org/10.3167/ca. 2013.310105

Hastrup K (2018) A history of climate change: inughuit responses to changing ice conditions in north-West Greenland. Clim Chang 151:67-78

Hiratsuka VY, Beans JA, Robinson RF, Shaw JL, Sylvester I, Dillard DA (2017) Self-determination in health research: an Alaska native example of tribal ownership and research regulation. Int J Environ Res Public Health 14(11):1324. https://doi.org/10.3390/ijerph14111324
Holm LK, Grenoble LA, Virginia RA (2011) A praxis for ethical research and scientific conduct in Greenland. Études/Inuit/Studies 35:187200. https://doi.org/10.7202/1012841 ar

Hovelsrud GK, Smit B (eds) (2010) Community adaptation and vulnerability in Arctic regions. Springer, Dordrecht

Huggel C, Carey M, Clague J, Kääb A (2015) The high-mountain cryosphere: environmental changes and human risks. Cambridge University Press, New York

Hulme M (2017) Weathered: cultures of climate. SAGE, London

Huntington HP, Eerkes-Medrano L (2017) Stakeholder perspectives. AMAP. Adaptation actions for a changing Arctic - perspectives from the Bering/Chukchi/Beaufort region. Arctic Monitoring and Assessment Programme, Oslo, In, pp 11-38

Huntington HP, Begossi A, Gearheard SF, Kersey B, Loring P, Mustonen T, Paudel PK, Silvano RAM, Vave R (2017) How small communities respond to environmental change: patterns from tropical to polar ecosystems. Ecol Soc 22:9. https://www.ecologyandsociety.org/ vol22/iss3/art9/

Inuit Circumpolar Council-Alaska (2015) Alaskan Inuit food security conceptual framework: how to assess the Arctic from an Inuit perspective. Technical Report, Inuit Circumpolar Council-Alaska, Anchorage

ITK (2018) National Inuit Strategy on Research. Inuit Tapiriit Kanatami, Ottawa

Ittaq (2019) Ittaq Heritage and Research Centre. https://ittaq.ca/. Last accessed 30 Jan 2019

Johnson N, Behe C, Danielsen F, Krümmel E-M, Nickels S, Pulsifer PL (2016) Community-based monitoring and indigenous knowledge in a changing Arctic. Inuit Circumpolar Council, Ottawa

Kawagley AO (2006) A Yupiaq worldview: a pathway to ecology and spirit. In: Waveland Press. Long Grove, Illinois

Kirmayer LJ, Sehdev M, Whitley R, Dandeneau SF, Isaac C (2009) Community resilience: models, metaphors and measures. J Aborig Health 5:62-117

Klenk N, Meehan K (2015) Climate change and transdisciplinary science: problematizing the integration imperative. Environ Sci Policy 54: 160-167. https://doi.org/10.1016/j.envsci.2015.05.017

Krupnik I, Aporta C, Gearheard S, Laidler GJ, Holm LK (2010) SIKU: knowing our ice: documenting Inuit sea-ice knowledge and use. Springer, New York

Lightfoot S (2016) Global indigenous politics: a subtle revolution. Routledge, New York

Liverman DM (2009) Conventions of climate change: constructions of danger and the dispossession of the atmosphere. J Hist Geogr 35: 279-296. https://doi.org/10.1016/j.jhg.2008.08.008

McCubbin SG, Pearce T, Ford JD, Smit B (2017) Social-ecological change and implications for food security in Funafuti, Tuvalu. Ecol Soc 22(1):53. https://doi.org/10.5751/ES-09129-220153

McDowell JZ, Hess JJ (2012) Accessing adaptation: multiple stressors on livelihoods in the Bolivian highlands under a changing climate. Glob Environ Chang 22:342-352. https://doi.org/10.1016/j. gloenvcha.2011.11.002

Noongwook G, the Native Village of Savoonga, the Native Village of Gambell, Huntington HP, George JC (2007) Traditional knowledge of the bowhead whale (Balaena mysticetus) around St. Lawrence Island, Alaska. Arctic 60:47-54. http://www.jstor.org/stable/ 40513157

Orlove B, Wiegandt E, Luckman B (2008) Darkening peaks: glacier retreat, science, and society. University of California Press, Berkeley, California

Pearce T, Ford J, Willox AC, Smit B (2015) Inuit traditional ecological knowledge (TEK), subsistence hunting and adaptation to climate change in the Canadian Arctic. Arctic 68:233-245. http://www. jstor.org/stable/43871322

Pfeifer P (2018) An Inuit critique of Canadian Arctic research. Northern Public Affairs 6(1):29-35 
Piper L (2012) The Arctic and subarctic in global environmental history. In: McNeill JR, Mauldin ES (eds) A companion to global environmental history. Blackwell, Oxford, pp 153-166

Prno J, Bradshaw B, Wandel J, Pearce T, Smit B, Tozer L (2011) Community vulnerability to climate change in the context of other exposure-sensitivities in Kugluktuk, Nunavut. Polar Res 30(1): 7363. https://doi.org/10.3402/polar.v30i0.7363

Radin J, Kowal E (2017) Cryopolitics: frozen life in a melting world. MIT Press, Cambridge, MA

Rasmussen RO, Hovelsrud GK, Gearheard S (2015) Community viability and adaption. In: Larsen JN, Fondahl G (eds) Arctic human development report II: regional processes and global linkages. Nordic Council of Ministers, Copenhagen, pp 427-478

Reid P, Vogel C (2006) Living and responding to multiple stressors in South Africa - glimpses from KwaZulu-Natal. Glob Environ Chang 16:195-206. https://doi.org/10.1016/j.gloenvcha.2006.01.003

Rosen J (2017) Arctic 2.0: what happens after all the ice goes? Nature 542:152-154. https://doi.org/10.1038/542152a

Ruiz R (2015) Media environments: icebergs/xcreens/history. J Northern Stud 9:33-50. http://urn.kb.se/resolve?urn=urn:nbn:se:umu:diva121014

Serreze MC (2018) Brave new Arctic: the untold story of the melting north. In: Princeton University Press. Princeton

Sidortsov R, Ivanova A, Stammler F (2016) Localizing governance of systemic risks: a case study of the power of Siberia pipeline in Russia. Energy Res Soc Sci 16:54-68. https://doi.org/10.1016/j. erss.2016.03.021

Smit B, Wandel J (2006) Adaptation, adaptive capacity and vulnerability. Glob Environ Chang 16(3):282-292. https://doi.org/10.1016/j. gloenvcha.2006.03.008

Smith LT (2012) Decolonizing methodologies: research and Indigenous peoples, 2nd edn. Zed Books, New York

Stammler F (2013) Narratives of adaptation and innovation: ways of being mobile and mobile technologies among reindeer nomads in the Russian Arctic. In: Miggelbrink J, Habeck JO, Mazzullo N,
Koch P (eds) Nomadic and indigenous spaces: productions and cognitions. Ashgate, Farnham, Surrey, pp 221-245

Stammler F, Ivanova A (2016a) Confrontation, coexistence or co-ignorance? Negotiating human-resource relations in two Russian regions. Extract Ind Soc 3:60-72. https://doi.org/10.1016/j.exis. 2015.12.003

Stammler F, Ivanova A (2016b) Resources, rights and communities: extractive mega-projects and local people in the Russian Arctic. Eur Asia Stud 68(7):1220-1244. https://doi.org/10.1080/09668136. 2016.1222605

Stuhl A (2016) Unfreezing the Arctic: science, colonialism, and the transformation of Inuit lands. University of Chicago Press, Chicago

Swyngedouw E (2010) Apocalypse forever? Post-political populism and the spectre of climate change. Theory Cult Soc 27:213-232. https:// doi.org/10.1177/0263276409358728

Tyler NJC, Turi JM, Sundset MA, Strøm Bull K, Sara MN, Reinert E, Oskal N, Nellemann C, McCarthy JJ, Mathiesen SD, Martello ML, Magga OH, Hovelsrud GK, Hanssen-Bauer I, Eira NI, Eira IMG, Corell RW (2007) Saami reindeer pastoralism under climate change: applying a generalized framework for vulnerability studies to a subarctic social-ecological system. Glob Environ Chang 17(2):191206. https://doi.org/10.1016/j.gloenvcha.2006.06.001

Watt-Cloutier S (2015) The right to be cold: one woman's story of protecting her culture, the Arctic and the whole planet. Allen Lane, Toronto

Wilson SC, Trukhanova I, Dmitrieva L, Dolgova E, Crawford I, Baimukanov M, Baimukanov T, Ismagambetov B, Pazylbekov M, Jüssi M, Goodman SJ (2017) Assessment of impacts and potential mitigation for icebreaking vessels transiting pupping areas of an icebreeding seal. Biol Conserv 214:213-222. https://doi.org/10.1016/j. biocon.2017.05.028

\section{Affiliations}

\section{Henry P. Huntington ${ }^{1}$ (D) $\cdot$ Mark Carey $^{2} \cdot$ Charlene Apok $^{3} \cdot$ Bruce C. Forbes $^{4} \cdot$ Shari Fox ${ }^{5} \cdot$ Lene K. Holm $^{6}$. Aitalina Ivanova $^{7,8} \cdot$ Jacob Jaypoody $^{9} \cdot$ George Noongwook $^{10}$. Florian Stammler ${ }^{4}$}

1 Huntington Consulting, 23834 The Clearing Dr, Eagle River, AK 99577, USA

2 Robert D. Clark Honors College, University of Oregon, Eugene, OR 97403, USA

3 Southcentral Foundation, Anchorage, AK 99508, USA

4 Arctic Centre, University of Lapland, 96101 Rovaniemi, Finland

5 National Snow and Ice Data Center, University of Colorado Boulder, Boulder, CO 80309, USA
6 Greenland Climate Research Centre, Greenland Institute of Natural Resources, 3900 Nuuk, Greenland

7 Faculty of Law, North Eastern Federal University, 677000 Yakutsk, Republic of Sakha (Yakutia), Russia

8 Centre for Peace Studies, UiT the Arctic University of Norway, 9037 Tromsø, Norway

9 Clyde River, Canada

10 Savoonga Whaling Captains Association, Savoonga, AK 99769, USA 